\title{
Determination of the types of road accidents at roundabouts
}

\author{
Vladimir Rassokha ${ }^{1}$, Nikolai Nikitin ${ }^{2 *}$, Yulia Savina $^{2}$ \\ ${ }^{1}$ Orenburg State University, Faculty of Transport, 460018, Orenburg, Victory Avenue, 13, Russia \\ ${ }^{2}$ Immanuel Kant Baltic Federal University, Institute of Engineering and Technology, 236022, \\ Kaliningrad, Lieut.-Gen. Ozerova Street, 57, Russia
}

\begin{abstract}
The main purpose of this study was to identify and analyze the prevailing types of accidents at roundabouts. The relationship was revealed between certain types of accidents, the place of their occurrence, and the configuration of the roundabout. The study analyzed 321 accidents at 19 ring intersections. Four predominant crash types were identified: rear-end collision, collision with vulnerable road users, side swipe collision, and entering circulate collision. The greatest number of accidents occurred at the weaving lane and at the entrances and exits of the roundabout. Dividing the ring intersections into separate sections to determine the location of the accident allows drawing conclusions on the nature of road traffic accidents and the impact of the roundabout design on safety.
\end{abstract}

\section{Introduction}

Roundabout is a type of intersection configuration strongly associated with improved road safety. International studies of intersections, which were transformed from regular ones to roundabouts, indicate significant reductions in road traffic accidents, especially with serious injuries and fatalities [1-7]. Roundabouts improve road safety by reducing the number of conflict points and traffic speed, which leads to a decrease in the severity of the consequences of road accidents [8]. According to the international studies, there are three predominant types of traffic accidents at roundabouts: collisions between vehicles entering the roundabout and those moving along it, collisions at roundabout exits, and collisions with vehicles driving ahead [9-12].

A large number of studies are focused on the characteristics of traffic safety at roundabouts, but due to the peculiarities of collecting data on road accidents in the Russian Federation, there is practically no information about the exact location of the accident. Therefore, this study is aimed at identifying and analyzing the most common types of accidents at roundabouts. Mandavilli [9] and Montella [10] analyzed accidents with consideration to their location on the ring intersection. The ideas proposed by these scientists were used by the authors to improve the accuracy of describing road traffic accidents. This study suggests distinguishing 11 sections, which makes it possible to better understand the cause of the accident, as well as to accurately take into account the location of vehicles on the roundabout. For each section, the prevailing type of accident is determined, which in turn

*Corresponding author: ninikitin@kantiana.ru 
connects the causes of the accident with the characteristics and configuration of the ring intersection. A similar approach has already been applied to other types of intersections, such as unsignalized intersections [13,14], motorway exits [15], and service roads [16].

The analysis involved road accidents that occurred from 2015 to 2021. The data for the research was taken from open sources: the traffic police database and the car communities. In total, information was received on 321 road traffic accidents resulting in property damage or injury, including 315 road accidents at 13 multi-lane roundabouts, 5 road accidents at 5 two-lane roundabouts, and 1 road accident at 1 single-lane roundabout. To classify accidents, the conditional ring intersection was divided into a certain number of sections (Figure 1) in accordance with the data obtained from the work of other researchers [9].

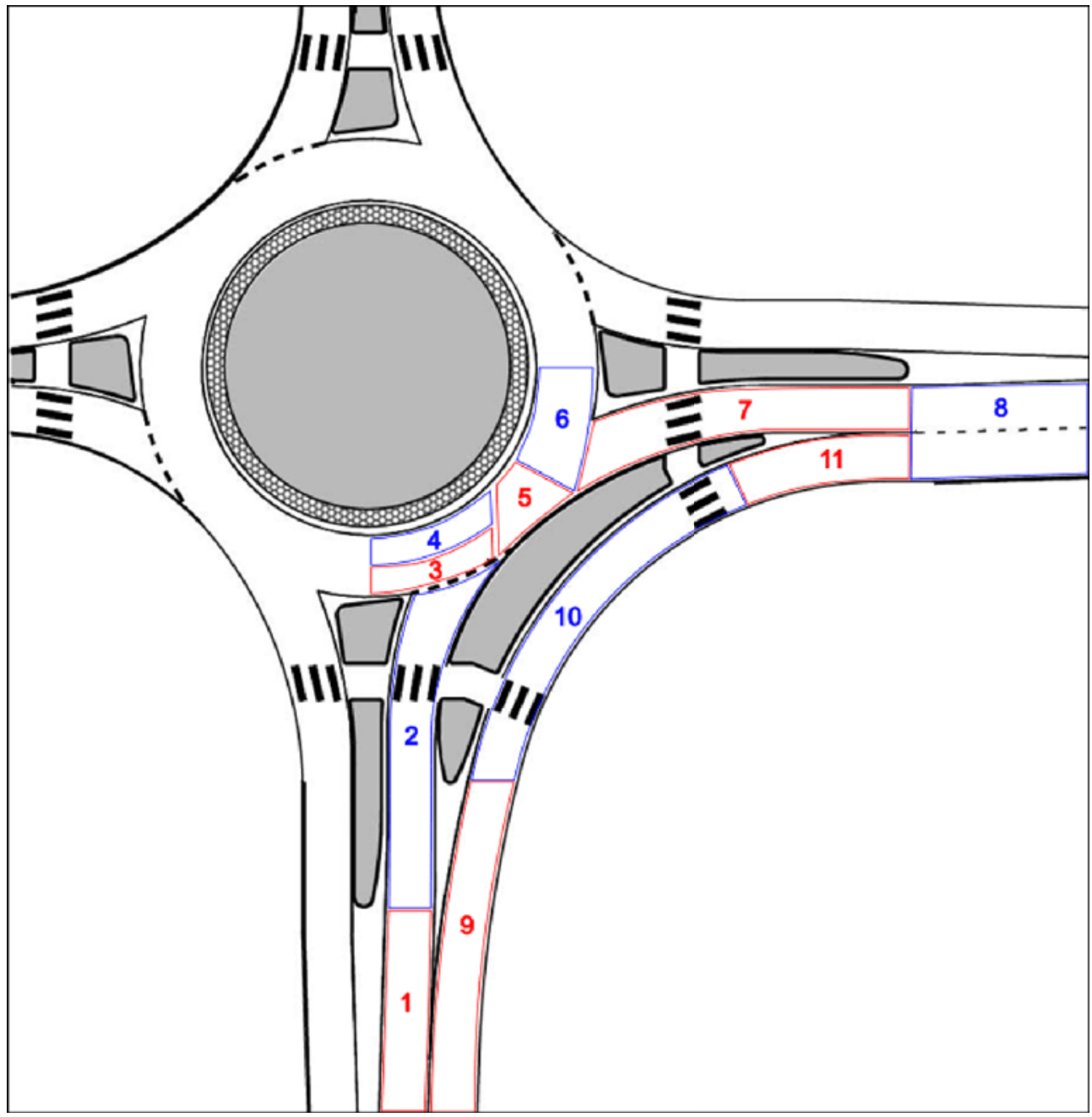

Fig. 1. Dividing the roundabout into sections.

The division into individual sections allows for a wide variety of roundabout configurations to be considered. Figure 1 shows the intersection that includes the largest number of elements, e.g. a bypass.

Due to the large number of different roundabout designs, the general characteristics of each section were determined (Table 1). 
Table 1. Roundabout sections and their description

\begin{tabular}{|c|c|}
\hline Roundabout section & Description \\
\hline \multicolumn{2}{|c|}{ Approach and entrance to the roundabout } \\
\hline Section 1 & $\begin{array}{l}25-150 \text { meters before the roundabout. Entering } \\
\text { traffic flows and congestion queues. }\end{array}$ \\
\hline Section 2 & $\begin{array}{l}0-25 \text { meters before the roundabout, up to the } \\
\text { marking. Includes pedestrian crossings. }\end{array}$ \\
\hline \multicolumn{2}{|c|}{ Roundabout roadway } \\
\hline Section 3 & $\begin{array}{l}\text { Located at the entrance to the roundabout } \\
\text { roadway, right after the marking. In the case of a } \\
\text { multi-lane roundabout, it occupies the outer and } \\
\text { middle traffic lanes. }\end{array}$ \\
\hline Section 4 & $\begin{array}{l}\text { Continuation of section 3. Located opposite the } \\
\text { entrance to the roundabout. If available, includes } \\
\text { a truck apron. In the case of a multi-lane } \\
\text { roundabout, it occupies the inner lane. }\end{array}$ \\
\hline Section 5 & $\begin{array}{l}\text { Located on the roundabout roadway, in the zone } \\
\text { of conflict points of weaving lane. It is advised } \\
\text { to locate the beginning and end of the section at } \\
5-10 \text { meters from the entrances and exits. }\end{array}$ \\
\hline Section 6 & $\begin{array}{l}\text { Located on the roundabout roadway opposite to } \\
\text { the roundabout exit. }\end{array}$ \\
\hline \multicolumn{2}{|c|}{ Roundabout exit } \\
\hline Section 7 & $\begin{array}{l}0-25 \text { meters after the roundabout roadway. } \\
\text { Includes pedestrian crossings. }\end{array}$ \\
\hline Section 8 & $\begin{array}{l}25-200 \text { meters or more. Outgoing traffic flow. } \\
\text { The size of the zone depends on the location of } \\
\text { the nearest intersections. }\end{array}$ \\
\hline \multicolumn{2}{|c|}{ Bypass } \\
\hline Section 9 & $\begin{array}{l}\text { The beginning of the lane for the bypass. } \\
\text { Located at the widening of the roadway. }\end{array}$ \\
\hline Section 10 & $\begin{array}{l}\text { A section that includes pedestrian crossings at } \\
\text { the entrance and exit from the roundabout. }\end{array}$ \\
\hline Section 11 & $\begin{array}{l}\text { The end of the lane for the bypass. Located at the } \\
\text { narrowing of the roadway. }\end{array}$ \\
\hline
\end{tabular}

\section{Methodology}

\subsection{Distribution of accidents by roundabouts and severity of consequences}

To display the real situation at intersections, the official statistics, which only take into account accidents with victims, were supplemented with data on accidents with material damage, which accounted for $82 \%$ of the total number of accidents. The data were distributed with consideration to the roundabout intersections at which the accident occurred (Table 2).

Table 2. Distribution of road accidents by roundabouts and severity of consequences

\begin{tabular}{|c|c|c|c|c|c|}
\hline № & $\begin{array}{c}\text { Number } \\
\text { of } \\
\text { accidents }\end{array}$ & $\begin{array}{c}\text { Road } \\
\text { accidents } \\
\text { with victims }\end{array}$ & $\begin{array}{c}\text { Road accidents } \\
\text { with serious } \\
\text { injuries }\end{array}$ & $\begin{array}{c}\text { Road } \\
\text { accidents } \\
\text { with fatalities }\end{array}$ & $\begin{array}{c}\text { Road accidents } \\
\text { with property } \\
\text { damage }\end{array}$ \\
\hline 1 & 186 & 12 & 2 & 1 & 174 \\
\hline 2 & 15 & 4 & 0 & 0 & 11 \\
\hline 3 & 5 & 4 & 0 & 0 & 1 \\
\hline
\end{tabular}




\begin{tabular}{|c|c|c|c|c|c|}
\hline № & $\begin{array}{c}\begin{array}{c}\text { Number } \\
\text { of } \\
\text { accidents }\end{array} \\
\end{array}$ & $\begin{array}{c}\text { Road } \\
\text { accidents } \\
\text { with victims }\end{array}$ & $\begin{array}{c}\text { Road accidents } \\
\text { with serious } \\
\text { injuries } \\
\end{array}$ & $\begin{array}{c}\text { Road } \\
\text { accidents } \\
\text { with fatalities } \\
\end{array}$ & $\begin{array}{c}\text { Road accidents } \\
\text { with property } \\
\text { damage }\end{array}$ \\
\hline 4 & 8 & 8 & 2 & 0 & 0 \\
\hline 5 & 7 & 7 & 1 & 0 & 0 \\
\hline 6 & 27 & 10 & 1 & 1 & 17 \\
\hline 7 & 61 & 2 & 0 & 0 & 59 \\
\hline 8 & 0 & 0 & 0 & 0 & 0 \\
\hline 9 & 5 & 3 & 1 & 0 & 2 \\
\hline 10 & 1 & 1 & 0 & 0 & 0 \\
\hline 11 & 1 & 1 & 0 & 1 & 0 \\
\hline 12 & 0 & 0 & 0 & 0 & 0 \\
\hline 13 & 1 & 1 & 0 & 0 & 0 \\
\hline 14 & 0 & 0 & 0 & 0 & 0 \\
\hline 15 & 1 & 1 & 1 & 0 & 0 \\
\hline 16 & 0 & 0 & 0 & 0 & 0 \\
\hline 17 & 0 & 0 & 0 & 0 & 0 \\
\hline 18 & 2 & 2 & 0 & 0 & 0 \\
\hline 19 & 1 & 1 & 0 & 0 & 0 \\
\hline Total & 321 & 57 & 8 & 3 & 264 \\
\hline & $100.00 \%$ & $17.76 \%$ & $2.49 \%$ & $0.93 \%$ & $82.24 \%$ \\
\hline
\end{tabular}

Roundabouts 1, 6, and 7 are characterized by the highest number of accidents, which is due to their location at the intersection of main city streets and high traffic intensity. However, it should be noted that roundabouts 2, 4, and 9 are in similar conditions, but the number of accidents on them is substantially lower. Such a difference may be due to various factors, the most likely of which can be the lack of accurate information on accidents with property damage. This fact requires additional research, which is beyond the scope of this work.

\subsection{Distribution of accidents by sections}

The largest number of accidents occurred in weaving lane on the roundabout roadway (Table 3). The sections at the entrances and exits of the roundabout are the next, with the minimum difference in the number of accidents.

Table 3. Distribution of road accidents by sections at circular intersections

\begin{tabular}{|c|c|c|}
\hline Roundabout section & Total amount of accidents & Percentage \\
\hline All sections & $\mathbf{3 2 1}$ & $\mathbf{1 0 0 . 0 0 \%}$ \\
\hline Section 1 & 22.00 & $6.85 \%$ \\
\hline Section 2 & 33.00 & $10.28 \%$ \\
\hline Section 3 & 21.00 & $6.54 \%$ \\
\hline Section 4 & 4.00 & $1.25 \%$ \\
\hline Section 5 & 65.00 & $20.25 \%$ \\
\hline Section 6 & 32.00 & $9.97 \%$ \\
\hline
\end{tabular}




\begin{tabular}{|c|c|c|}
\hline Roundabout section & Total amount of accidents & Percentage \\
\hline Section 7 & 47.00 & $14.64 \%$ \\
\hline Section 8 & 9.00 & $2.80 \%$ \\
\hline Section 9 & 3.00 & $0.93 \%$ \\
\hline Section 10 & 1.00 & $0.31 \%$ \\
\hline Section 11 & 3.00 & $0.93 \%$ \\
\hline Total for sections & & $74.77 \%$ \\
\hline Unknown section & & $25.23 \%$ \\
\hline
\end{tabular}

The minimum number of accidents was recorded in sections 9, 10, and 11, which may be due to the fact that only one of 19 roundabouts has a bypass.

It should also be noted that for $25 \%$ of accidents it is impossible to determine the section of the roundabout, due to the lack of an accurate road accident diagram. This problem can be solved by applying foreign experience in compiling collision diagrams to determine the nature of road accidents $[9,10]$. The advantage of this approach is the possibility to clearly identify the prevailing types of accidents at the roundabout, and the maneuvers of vehicles that led to the collision. Using the graphic design of the arrows, one can encode information about the time of day, weather, type of road traffic accidents, and the severity of injuries. Another approach to collecting data on road accidents is the application of neural networks that allow processing data on traffic flows in real time using video cameras located near streets and roads. The experience of collecting such information has already been applied by Russian researchers [17]. Further development of such detection systems can be the registration of road accidents with the possibility of reconstructing the road user trajectories, which will allow analyzing the causes of accidents to prevent similar accidents in the future.

\subsection{Types of accidents}

There are nine types of road traffic accidents in Russia [18]:

Table 4. Classification of road accidents in Russian legislation

\begin{tabular}{|l|l|}
\hline \multicolumn{1}{|c|}{ Type of accident } & \multicolumn{1}{c|}{ Description } \\
\hline Collision with a stationary vehicle & $\begin{array}{l}\text { An accident in which a moving vehicle collides } \\
\text { with a stationary vehicle or trailer. }\end{array}$ \\
\hline Collision with an obstacle & $\begin{array}{l}\text { An accident in which a moving vehicle collides } \\
\text { with a stationary object. }\end{array}$ \\
\hline Collision with a pedestrian & $\begin{array}{l}\text { An accident in which: } \\
\text { - a moving vehicle hits a person; } \\
\text { - or a person bump into a moving vehicle; } \\
\text { - or a person is injured by the cargo transported } \\
\text { by a vehicle that protrudes beyond the } \\
\text { dimensions of the vehicle. }\end{array}$ \\
\hline \multirow{3}{*}{ Collision with a cyclist } & $\begin{array}{l}\text { An accident in which a moving vehicle collides } \\
\text { with a cyclist or a cyclist collides with a moving } \\
\text { vehicle. }\end{array}$ \\
\hline Collision with an animal & $\begin{array}{l}\text { An accident in which a moving vehicle collides } \\
\text { with birds, wild or domestic animals, or the } \\
\text { animals and birds hit a moving vehicle, resulting } \\
\text { in injury to people or property damage. }\end{array}$ \\
\hline \multirow{2}{*}{ Collision with an animal-drawn vehicle } & $\begin{array}{l}\text { An incident in which a moving vehicle collides } \\
\text { with draft animals or animal-drawn carts, or the } \\
\text { draft animals or animal-drawn carts hit a moving } \\
\text { vehicle. }\end{array}$ \\
\hline
\end{tabular}




\begin{tabular}{|c|c|}
\hline Type of accident & Description \\
\hline Crash & $\begin{array}{l}\text { An accident in which moving vehicles crash: } \\
\text { - with each other; } \\
\text { - or with railway rolling stock; } \\
\text { - or with a suddenly stopped vehicle. }\end{array}$ \\
\hline Roll-over & $\begin{array}{l}\text { An accident in which a moving vehicle } \\
\text { overturns. }\end{array}$ \\
\hline Other accidents & $\begin{array}{l}\text { They include: } \\
\text { - the fall of a transported cargo on a person, an } \\
\text { animal, or other vehicle, } \\
\text { - collisions with a suddenly appeared obstacle (a } \\
\text { dropped load, a detached wheel, etc.), } \\
\text { - collisions with persons who are not road users, } \\
\text { - passengers falling from or inside a moving } \\
\text { vehicle due to sudden braking, acceleration, or a } \\
\text { change in direction of movement, et al. }\end{array}$ \\
\hline
\end{tabular}

The analysis of this classification showed that it does not meet the objectives of this study. In this regard, a different classification is proposed, which allows a more complete description of the types of accidents occurring at roundabouts:

Table 5. Road accident classification for roundabouts

\begin{tabular}{|l|l|}
\hline \multicolumn{1}{|c|}{ Type of accident } & \multicolumn{1}{c|}{ Description } \\
\hline Run-off-road & $\begin{array}{l}\text { A single vehicle accident in which the vehicle drives off the road and } \\
\text { collides with an off-road object, such as a traffic sign or traffic island. }\end{array}$ \\
\hline Collision with the central island & $\begin{array}{l}\text { A single vehicle accident in which a vehicle collides with a center } \\
\text { island. }\end{array}$ \\
\hline Wrong way & $\begin{array}{l}\text { A road user enters the roundabout in an unacceptable direction or } \\
\text { moves along the roundabout in the wrong direction. }\end{array}$ \\
\hline Rear-end collision & $\begin{array}{l}\text { An accident in which a vehicle collides with the rear of a vehicle } \\
\text { ahead. }\end{array}$ \\
\hline Loss of control & $\begin{array}{l}\text { An accident that occurs as a result of the loss of control by one or } \\
\text { more road users. }\end{array}$ \\
\hline $\begin{array}{l}\text { Collision with vulnerable road } \\
\text { users }\end{array}$ & cyclists, motorcyclists, and users of low mobility devices. \\
\hline Entering circulate collision & $\begin{array}{l}\text { An accident in which an entering vehicle does not give way and } \\
\text { collides with a vehicle on a ring intersection. }\end{array}$ \\
\hline Side swipe collision & $\begin{array}{l}\text { An accident that occurred when changing a lane on a roundabout or } \\
\text { at a roundabout exit. }\end{array}$ \\
\hline Falling passenger & An accident in which a passenger falls in public transport. \\
\hline
\end{tabular}

The proposed classification was developed based on the analysis of the most common accidents. It allows classification not by the participants, but by the nature of the incident. The types of accidents can be modified, for example, «collision with the central island» can be combined with «loss of control». It should be noted that Russian studies on the identification of factors that affect road accidents [19] will make it possible to further refine this classification and to determine what information should be included in the accident diagram. 


\subsection{The relationship between the type of accident and the location on the roadway}

The types of road accidents were divided into sections at the roundabout in accordance with the place of their occurrence (Table 6).

Table 6. Types of road accidents distributed by sections at the roundabout

\begin{tabular}{|c|c|c|}
\hline Type of accident & Number of accidents & Percentage \\
\hline All sections & 321 & $100.00 \%$ \\
\hline Run-off-road & 4 & $1.25 \%$ \\
\hline Section 7 & 2 & $0.62 \%$ \\
\hline Section 9 & 1 & $0.31 \%$ \\
\hline Section 11 & 1 & $0.31 \%$ \\
\hline Collision with the central island & 3 & $0.93 \%$ \\
\hline Section 4 & 3 & $0.93 \%$ \\
\hline Wrong way & 2 & $0.62 \%$ \\
\hline Section 3 & 2 & $0.62 \%$ \\
\hline Rear-end collision & 57 & $17.76 \%$ \\
\hline Section 1 & 2 & $0.62 \%$ \\
\hline Section 2 & 8 & $2.49 \%$ \\
\hline Section 3 & 6 & $1.87 \%$ \\
\hline Section 5 & 19 & $5.92 \%$ \\
\hline Section 6 & 3 & $0.93 \%$ \\
\hline Section 7 & 10 & $3.12 \%$ \\
\hline Section 8 & 6 & $1.87 \%$ \\
\hline Section 9 & 1 & $0.31 \%$ \\
\hline Section 11 & 2 & $0.62 \%$ \\
\hline Loss of control & 6 & $1.87 \%$ \\
\hline Section 5 & 2 & $0.62 \%$ \\
\hline Section 6 & 1 & $0.31 \%$ \\
\hline Section 7 & 2 & $0.62 \%$ \\
\hline Section 9 & 1 & $0.31 \%$ \\
\hline Collision with vulnerable road users & 26 & $8.10 \%$ \\
\hline Section 1 & 1 & $0.31 \%$ \\
\hline Section 2 & 11 & $3.43 \%$ \\
\hline Section 5 & 1 & $0.31 \%$ \\
\hline Section 7 & 10 & $3.12 \%$ \\
\hline Section 8 & 2 & $0.62 \%$ \\
\hline Section 10 & 1 & $0.31 \%$ \\
\hline Entering circulate collision & 15 & $4.67 \%$ \\
\hline Section 2 & 2 & $0.62 \%$ \\
\hline Section 3 & 9 & $2.80 \%$ \\
\hline
\end{tabular}




\begin{tabular}{|c|c|c|}
\hline Type of accident & Number of accidents & Percentage \\
\hline Section 5 & 3 & $0.93 \%$ \\
\hline Side swipe collision & $\mathbf{7 8}$ & $\mathbf{2 4 . 3 0 \%}$ \\
\hline Section 1 & 11 & $3.43 \%$ \\
\hline Section 2 & 5 & $1.56 \%$ \\
\hline Section 3 & 2 & $0.62 \%$ \\
\hline Section 4 & 1 & $0.31 \%$ \\
\hline Section 5 & 22 & $6.85 \%$ \\
\hline Section 6 & 22 & $6.85 \%$ \\
\hline Section 7 & 15 & $4.67 \%$ \\
\hline Falling passenger & $\mathbf{5}$ & $\mathbf{1 . 5 6 \%}$ \\
\hline Section 1 & 1 & $0.31 \%$ \\
\hline Section 3 & 1 & $0.31 \%$ \\
\hline Section 5 & 1 & $0.31 \%$ \\
\hline Section 6 & 1 & $0.31 \%$ \\
\hline Section 7 & 1 & $0.31 \%$ \\
\hline
\end{tabular}

Table 6 shows that a significant number of accidents occurred in sections 5 and 7 . Rearend collisions most often occurred on the roundabout weaving lane and at the exit in section 7. Entering circulate collisions occurred in section 5 due to the characteristics of the participants and the roundabout configuration, in this case, one of the participants was a large cargo vehicle. Sections 2 and 7 are characterized by a predominance of accidents involving vulnerable road users. Side swipe collisions most often occurred in sections 1, 5, 6, and 7, which is largely due to the presence of several lanes at the approach to the roundabout and directly on the roundabout roadway. Only in section 3 there was an accident with an incorrect choice of direction of movement, but the sample size of this type of accident is too small to draw any further conclusions.

The four main types of accidents - rear-end collisions, collisions with vulnerable road users, entering circulate collisions, and side swipe collisions - account for more than half $(55 \%)$ of all roundabout accidents.

\section{Conclusion}

This study was aimed at the determination of the types of accidents at roundabouts. The number of intersections studied was relatively small (19 roundabouts) and as a result, the study may have some limitations. However, the purpose of this paper was not to compare the roundabouts with each other, but to determine the types of prevailing road traffic accidents, as well as the places of their occurrence. The resulting sample of 321 accidents at ring intersections coped with this goal.

There is reason to believe that dividing the roundabouts into sections and identifying the most frequent accidents in these sections will provide new data on the nature of road accidents and the impact of the roundabout configuration on their occurrence.

The results obtained show that road accidents more often occurred at the weaving lane (section 5), entrances (sections 1-3), and exits (sections 6 and 7). The four most common types of accidents have also been identified. Side swipe collision is the most common type of crash at the intersections under study. The highest percentage of such accidents is at the weaving lane and at the exit sections, which indicates that drivers have violated the trajectory of movement and tailgated when changing lanes. Rear-end collisions most often occurred at the weaving lane of the roundabout and at the exit (section 7). From the point of view of road 
safety, the study results indicate the presence of a systemic problem at multi-lane roundabouts, which manifests itself in the occurrence of accidents in the most conflict areas.

Pedestrian crossings located near roundabouts are a source of increased danger. It is noticeable by the prevalence of this type of road traffic accident in sections 2 and 7 . Despite the decrease in speed on the approach to the roundabout, the complexity of the road network section forces the driver to distribute attention to many external factors, which leads to increased fatigue and inattention. Therefore, it is recommended to construct pedestrian crossings at a distance from the ring intersections to improve the safety of vulnerable road users, which is an established practice in other countries [7].

The results of this research work have identified promising areas for further research. Future studies of accidents occurring at roundabouts should explore in detail the relationship between the prevailing crash patterns, their location in terms of specific intersection sections, and roundabout characteristics such as speed limit, location (urban or regional), road geometry, multi-lane, and the presence of bypasses.

Further development of road traffic accident research depends directly on the quality and quantity of the source data, which requires a change in the approach to their collection and processing. It is proposed to make mandatory the transfer of data from insurance companies and accident managers about road accidents that have caused only material damage.

\section{References}

1. U. Brude and J. Larsson, Nord. Road Transp. Res. 2, 17 (2000)

2. B. De Brabander, E. Nuyts, and L. Vereeck, J. Safety Res. 36, 289 (2005)

3. R. Elvik, Transp. Res. Rec. J. Transp. Res. Board 1847, 1 (2003)

4. R. Elvik, A. Høye, T. Vaa, and M. Sørensen, The Handbook of Road Safety Measures (Emerald Group Publishing Limited, 2009)

5. R. A. Retting, B. N. Persaud, P. E. Garder, and D. Lord, Am. J. Public Health 91, 628 (2001)

6. Transportation Research Board, Roundabouts: An Informational Guide - Second Edition (The National Academies Press, Washington, DC, 2010)

7. L. Rodegerdts, M. Blogg, E. Wemple, and E. Myers, Roundabouts in the United States (Transportation Research Board, Washington, D.C., 2007)

8. S. U. Jensen, Transp. Res. Rec. J. Transp. Res. Board 2389, 22 (2013)

9. S. Mandavilli, A. T. McCartt, and R. A. Retting, Traffic Inj. Prev. 10, 44 (2009)

10. A. Montella, Accid. Anal. Prev. 43, 1451 (2011)

11. M. Park, D. Lee, and J.-J. Park, J. Adv. Transp. 2018, 1 (2018)

12. H. Isebrands, Transp. Res. Rec. J. Transp. Res. Board 2096, 1 (2009)

13. R. A. Retting, H. B. Weinstein, and M. G. Solomon, J. Safety Res. 34, 485 (2003)

14. H. Gstalter and W. Fastenmeier, Accid. Anal. Prev. 42, 225 (2010)

15. F. Praticò, R. Vaiana, and V. Gallelli, in Urban Transp. XVIII (A Coruña, Spain, 2012), pp. 383-394

16. A. J. Khattak and F. Targa, Transp. Res. Rec. J. Transp. Res. Board 1877, 106 (2004)

17. K. Khazukov, V. Shepelev, T. Karpeta, S. Shabiev, I. Slobodin, I. Charbadze, and I. Alferova, J. Big Data 7, 84 (2020)

18. S. N. Martynyuk, Soc. Polit. Econ. Law 134 (2016)

19. G. Yakupova, P. Buyvol, and V. Shepelev, Transp. Res. Procedia 50, 735 (2020) 